\title{
Potential forage species for deer in the south- ern mixed prairie
}

\author{
SARA H. SCHWEITZER, FRED C. BRYANT, AND DAVID B. WESTER
}

\begin{abstract}
Authors are research assistant, Oklahoma Coop. Fish Wildl. Res. Unit., Oklahoma State University, Stillwater 74078; professor and associate professor, Texas Tech University, Lubbock 79409. At the time of the research, the senior author was research assistant, Range and Wildlife Department, Texas Tech University.
\end{abstract}

\begin{abstract}
Improving wildlife habitat through the introduction of nutritious forage species is a management tool that may be used to increase target populations such as deer. By increasing deer numbers the potential of leasing hunting rights on private land is improved. Our objectives were to evaluate and compare establishment and production of 2 browse species and to determine the production and nutritional quality among 6 forb species in rangeland conditions. Browse species were littleleaf lead-tree (Leucaena retusa Gray) and four-wing saltbush (Atriplex canescens (Pursh) Nutt.). Forb species were 'Cody' alfalfa (Medicago sativa L.), 'Renumex' sainfoin (Onobrychis viciffolia Scop.), 'Howard' subterranean clover (Trifolium subterraneum L.), 'Nungarin' subterranean clover ( $T$. subterraneum L.), 'Eldorado' Englemann daisy (Engelmannia pinnatifida Nutt.), 'Sabine' Illinois bundleflower (Desmanthus illinoensis (Michx.) MacM.), and 'Plateau' awnless bush sunflower (Simsia calva (Engelm. \& Gray) Gray). Establishment for littleleaf lead-tree was $21 \%$. Successful four-wing saltbush plants produced a greater volume $\left(\mathrm{m}^{3}\right)$ of plant material than littleleaf lead-tree. Littleleaf lead-tree leaf material contained crude protein (CP) values from 11.6 to $16.9 \%$. Of the cool-season forbs, alfalfa, and sainfoin produced the most above-ground phytomass at 23.6 and $22.6 \mathrm{~g} / \mathrm{m}$ of planted row, respectively. The subclovers produced intermediate amounts of phytomass while Engelmann daisy produced negligible amounts at phytomass of $4.2 \mathrm{~g} / \mathrm{m}$ of planted row. Warm-season forages, awnless bush sunflower, and Illinois bundleflower produced an average of 115.1 and $120.2 \mathrm{~g} / \mathrm{m}$ of planted row, respectively. Seasonal CP means were greatest for alfalfa (16.5\%) and awnless bush sunflower (16.1\%). Our results suggest that littleleaf lead-tree, awnless bush sunflower, and Illinois bundleflower would supply adequate supplemental forage from summer to fall; subterranean clovers, alfalifa, and sainfoin would provide forage from winter through spring. Four-wing saltbush could provide forage year-round.
\end{abstract}

Key Words: browse, crude protein, forbs, habitat management, Odocoileus spp., phytomass

Increasing forage quality and quantity is a worthy management goal for increasing deer populations. Landowners are generally interested in such management due to the economic return for recreational opportunities on their rangeland (Steinbach and Ramsey 1988). At present, white-tailed deer (Odocoileus virginianus) are the single-most hunted big game species in Texas and generate the greatest economic return (Smith 1986).

Primary funding was provided by the Caesar Kleberg Foundation. The USDA, SCS Plant Materials Center, Knox City, Texas, and George Warner Seed Company, Hereford, Texas, provided seed for the study. The Nitrogen Corp., Milwaukee, Wisconsin, supplied inoculant and Pel Gel adhesive for legumes. The authors thank Ron Sosebee, Carlton Britton, and the late Bill Dahl for manuscript review. L.C. Bradley provided invaluable field and editorial assistance. This is technical article T-9-632 of the College of Agricultural Sciences, Texas Tech University.

Manuscript accepted 18 Apr. 1992.
Both domestic agricultural and native plant species have been planted as supplemental food plots to increase deer numbers (Herbel 1986, Vanderhoof and Jacobson 1989). White-tailed deer select primarily the succulent, new green growth of browse, forbs, and grasses, with browse and forbs being most preferred (Bryant et al. 1979, Sowell et al. 1985). Thus, these forage types should be emphasized when establishing food plots for deer. Periods of nutritional stress experienced by deer in the southern mixed prairie coincide with late summer to winter when forage quality is low because forbs are scarce and grasses are mature and of low nutritional value. In addition, periodic summer droughts may occur during the nutritionally demanding periods of lactation, antler growth, and fawn growth, increasing the nutritional problems facing deer populations. Introduction of evergreen and droughttolerant shrubs could provide protein, phosphorus, and energy particularly during the winter stress periods (Cook 1972, Dietz 1972, Stidham et al. 1982). Forbs and legumes could supplement deer diets from spring through autumn.

Our study attempted to assess the feasibility of introducing potentially beneficial forages to the southern mixed prairie region of Texas, a region of low deer densities and insufficient forage (Cook and Harwell 1978, Wiggers et al. 1984, Bryant and Morrison 1985). The objective was to determine phytomass production and nutritional quality among 2 browse and 6 forb species in rangeland conditions.

\section{Study Area}

The study was conducted on a 7,300-ha private ranch in Foard County, about $8 \mathrm{~km}$ west of Crowell, Tex. The ranch is located in the southern mixed prairie, which is characterized by rolling to moderately rough terrain (Cook and Harwell 1978) with elevations of 427 to $520 \mathrm{~m}$ (Koos and Dixon 1964). Although the average annual precipitation is $61 \mathrm{~cm}$, there is considerable annual variation. Rainfall primarily occurs as localized, convective thunderstorms from May to October. Winters are mild, although abrupt temperature changes may occur as a result of cold fronts. Summers are hot with daily maximum temperatures often above $38^{\circ} \mathrm{C}$. High temperatures are generally accompanied by low humidity and light winds. The average growing season lasts about 220 days (1 April to 10 November).

Study plots were located on level rangeland of the TillmanVernon soil association. Although soil nutrient analyses detected differences among soil nutrients on study plots, no soil nutrients were limiting to plant performance. Soil texture ranged from clay to clay loam. Native vegetation included tall and mid-grasses with an overstory of honey mesquite (Prosopis glandulosa Torr. var. glandulosa), red-berry juniper (Juniperus pinchotii Sudw.), and lotebush (Ziziphus obtusifolia (T. \& G.) Gray) [scientific and common names according to Correll and Johnston (1979)]. All livestock had been removed from the ranch 3 years before initia- 
Table 1. Establishment means ${ }^{1}(\%)$ and standard errors (in parentheses) for four-wing saltbush (Atriplex canescens (Pursh) Nutt.) planted 19-20 Sept.and 13-15 Oct. 1986 in Foard County, Texas.

\begin{tabular}{|c|c|c|c|c|c|c|c|c|c|c|c|c|}
\hline \multirow[b]{3}{*}{ Planting date } & \multicolumn{12}{|c|}{ Evaluation-month (1987) } \\
\hline & \multicolumn{2}{|c|}{ June } & \multicolumn{2}{|c|}{ July } & \multicolumn{2}{|c|}{ Aug. } & \multicolumn{2}{|c|}{ Sept. } & \multicolumn{2}{|c|}{ Oct. } & \multicolumn{2}{|c|}{ Nov. } \\
\hline & Sept. & Oct. & Sept. & Oct. & Sept. & Oct. & Sept. & Oct. & Sept. & Oct. & Sept. & Oct. \\
\hline Means (\%) & 0.3 & 0.3 & 0.4 & 0.3 & 0.3 & 0.2 & 0.3 & 0.2 & 0.3 & 0.2 & 0.3 & 0.2 \\
\hline $\begin{array}{l}\text { Standard (\%) } \\
\text { Errors }\end{array}$ & $(0.1)$ & $(0.0)$ & $(0.2)$ & $(0.0)$ & $(0.2)$ & $(0.0)$ & $(0.2)$ & $(0.0)$ & $(0.2)$ & $(0.0)$ & $(0.2)$ & $(0.0)$ \\
\hline
\end{tabular}

IN $=4$ samples per mean.

tion of this study.

\section{Methods}

\section{Browse Species}

Two browse species were selected for planting based on their potential nutritive value during winter or mid- to late-summer, palatability, and potential adaptability to the study area (Vines 1960, USDA For. Serv. 1974, Correll and Johnston 1979).

Four, 2-ha plots were selected with similar topography and soil type. Plots were cleared with a bulldozer, deep-plowed, and disced. A potential winter forage species, four-wing saltbush (Atriplex canescens (Pursh) Nutt.), was seeded on 19-20 September 1986 at 2 plots, and 13-15 October 1986 at the remaining 2 plots. On each plot, this species was randomly assigned to 3 rows. Our manual seeding method simulated broadcast seeding, followed by light harrowing to insure seed-soil contact, on a well-disced seedbed. Plots were not fenced to exclude ungulates because no livestock were on the ranch, and deer densities, determined by helicopter surveys (fall 1986, fall 1987), were extremely low ( 1 deer per 265 ha). Fencing for small herbivores (e.g., lagomorphs) was cost prohibitive.

On each plot, the number of live seedlings was counted within 15-m randomly selected transects on 2 of 3 rows. Using the known seeding rate, percent establishment was calculated monthly from June to November 1987 . The volume $\left(\mathrm{m}^{3}\right)$ of four-wing saltbush was determined 21 months after seeding according to Bryant and Kothmann (1979).

Littleleaf lead-tree (Leucaena retusa Gray), the summer forage shrub, was seeded in early May 1987 on 2 plots in the same manner as four-wing saltbush. However, seeds were scarified by immersing in boiling water for $1 \mathrm{~min}$, rinsing with cool water, drying overnight at room temperature, then inoculating with bacteria (Rihizobium spp.) before planting. Percent establishment of lead-tree seedlings was determined for 5 evaluation-months (July to November 1987). Transect length was reduced to $0.5-\mathrm{m}$ because of high seedling density.

Establishment data of browse species over time were analyzed using analysis of variance (ANOVA) in a completely randomized design, split-split plot arrangement. Species' means were separated using Fisher's Least Significant Difference (FLSD) procedure (Steele and Torrie 1980:176). The level of significance was 0.05 in this and all subsequent statistical tests.

The abundant number of seedlings produced by littleleaf leadtree allowed six, $0.5-\mathrm{m}$ segments from each plot to be clipped in October 1987. Clipped forage was dried in a forced-air oven at $60^{\circ}$ $\mathrm{C}$ to a constant weight. Leaves were separated from stems and leaves were weighed to the nearest $0.01 \mathrm{~g}$. Lead-tree leaves were ground in a Thomas-Wiley laboratory mill to pass a $1-\mathrm{mm}$ mesh screen and were analyzed for nitrogen (\%) using the microKjeldahl technique (AOAC 1984). Leaf dry matter (\%) and organic matter (\%) were determined for reporting leaf crude protein (CP) $(\% \mathrm{~N} \div 6.25)$ on a dry organic matter basis. Leaf weight and $\mathrm{CP}$ data from each plot were analyzed using ANOVA in a completely randomized design to determine if there were plot differences in production and nutritional quality. Means were separated using FLSD procedure.

\section{Forb Species}

Four cool-season and 2 warm-season forbs were selected for evaluation based on their potential adaptability, palatability to herbivores, perennial or self-seeding characteristics, and nutrient quality (Vines 1960, Leffel 1973, Correll and Johnston 1979). Cool-season species, including 4 legumes, 'Cody' alfalfa (Medicago sativa L.), 'Renumex' sainfoin (Onobrychis viciifolia Scop.), 'Howard' subterranean clover (Trifolium subterraneum L.), 'Nungarin'subterranean clover ( $T$. subterraneum L.), and 1 composite, 'Eldorado' Engelmann daisy (Engelmannia pinnatifida Nutt.), were seeded on 19-20 September 1986 at 2 plots, and on 13-15 October 1986 at the 2 remaining plots. Warm-season species, including 1 legume, 'Sabine' Illinois bundleflower (Desmanthus illinoensis (Michx.) MacM.), and 1 composite, 'Plateau' awnless bush sunflower (Simsia calva (Engelm. \& Gray) Gray), were seeded on 16-17 May 1987 at 2 plots.

Plot design for forb species was the same as that for browse species. Cool-season forbs were seeded on 15 rows $(5$ species $\times 3$ replications per species) adjacent to browse species. Warm-season forbs were seeded ( 2 species $\times 3$ replications per species) on 16-17 May 1987 at 2 plots adjacent to fall browse and forb plantings. All legumes were inoculated with Rhizobium spp. before planting. Phytomass of each cool-season species was determined on each plot by clipping 2 randomly selected $0.5-\mathrm{m}$ segments from 2 of the species' 3 rows for 9 evaluation-months (December, April to November). Phytomass of warm-season species was determined using the same clipping method for 5 evaluation-months (July to November). No $0.5-\mathrm{m}$ segment was clipped more than once. Clipped forage was dried in a forced-air oven at $60^{\circ} \mathrm{C}$ to a constant weight then weighed to the nearest $0.01 \mathrm{~g}$. To determine production differences among species over time, cool-season forb phytomass data were analyzed as described for winter browse establishment data, and phytomass data of warm-season forbs were analyzed using an ANOVA in a randomized block design, split plot arrangement.

Dried forage of each forb species was analyzed for percent $\mathrm{CP}$ as described for lead-tree leaves. Percent CP of cool-season and warm-season forbs was analyzed statistically in the same manner as for browse.

\section{Results}

\section{Browse Species}

Four-wing saltbush maintained a fairly constant, but low, percent establishment through all evaluation-months (Table 1). The average volume per four-wing saltbush seedling was $2.08 \mathrm{~m}^{3}, 21$ months after planting.

Littleleaf lead-tree, the warm-season woody legume, had a mean establishment of $21 \%$. Five months after planting (October 1987), all rows of littleleaf lead-tree seedlings produced abundant leafy material $(\bar{x}=55 \mathrm{~g} / \mathrm{m})$ and percent $C P$ of leaf material varied from 


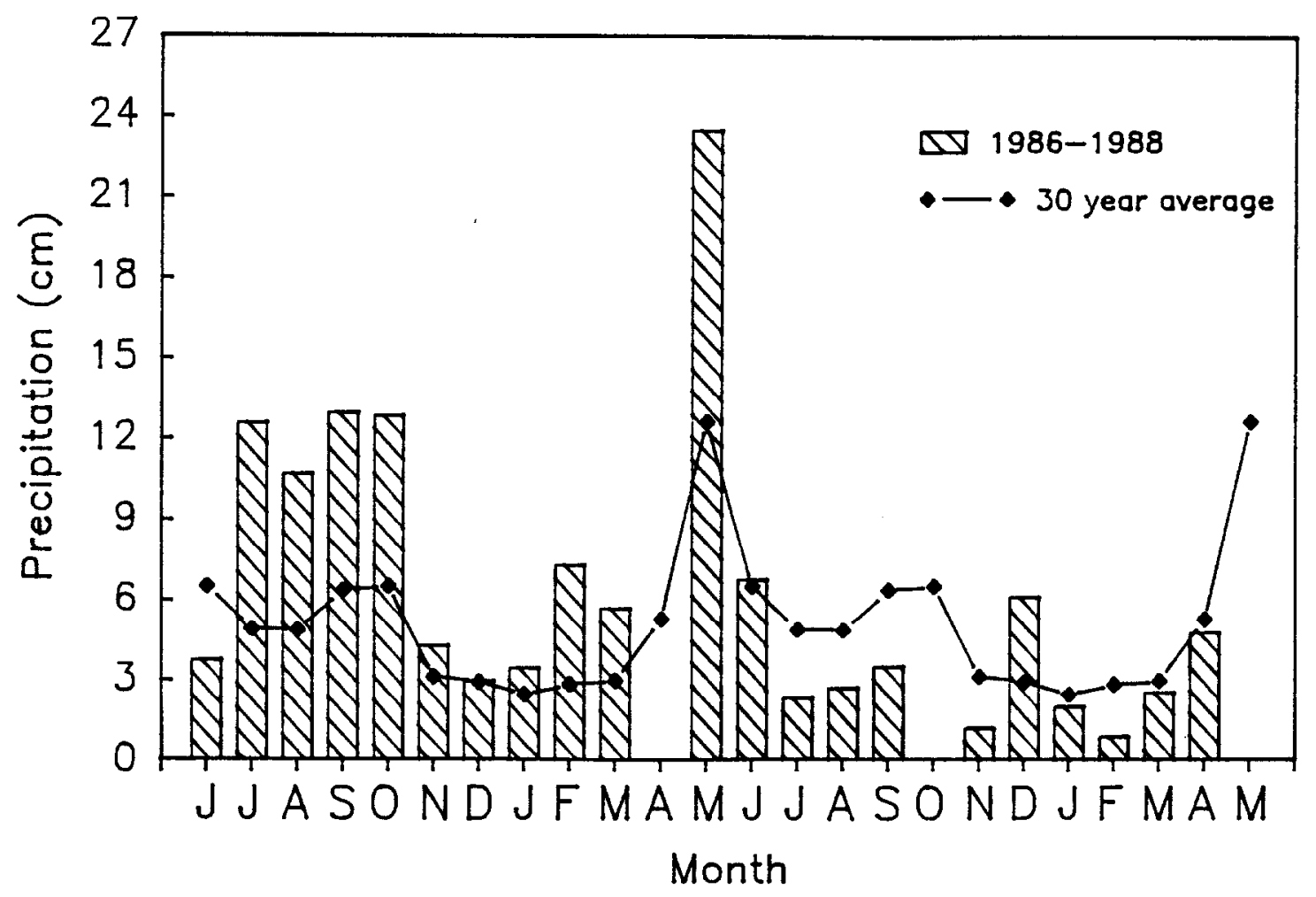

Fig. 1. Monthly and 30-year average precipitation (cm) recorded in Crowell, Texas, approximately $8 \mathrm{~km}$ west of the study site.

\section{$16.9 \%$ on plot 2 to $11.6 \%$ on plot 1 .}

\section{Forb Species}

Howard and Nungarin subterranean clovers were the only coolseason species that had germinated and produced enough aboveground vegetation to clip in December 1986(Table 2). Although by April 1987 alfalfa and sainfoin had produced above-ground vegetation, phytomass values of the subterranean clovers were still greater $(P<0.05)$. Howard and Nungarin subterranean clovers produced seed then became senescent in May 1987. From June to November 1987, alfalfa and sainfoin had the greatest $(P<0.05)$ phytomass values of the cool-season species. Engelmann daisy did not produce significant phytomass in any evaluation-month. Seeds of the subterranean clovers were expected to germinate by November 1987 . However, the preceding summer and fall were very dry (Fig. 1) and no regeneration occurred.

Phytomass of warm-season species, Illinois bundleflower and awnless bush sunflower (Table 3), exceeded those of the coolseason species from August to November 1987 (Table 2). By November 1987, leaves had become senescent and production declined. These warm-season species produced forage by July and continued to produce forage through October 1987, regardless of dry conditions.

Planting date did not affect cool-season forb CP concentrations $(P>0.05)$. In some sampling periods, 1 or more of the cool-season forbs did not produce enough phytomass to permit CP analysis (Table 4). Nungarin and Howard subterranean clovers had the greatest average CP concentrations, followed by alfalfa and sainfoin. Crude protein values of alfalfa, sainfoin, and Englemann daisy declined from July to November 1987 as they matured. An

Table 2. Monthly mean phytomass ${ }^{1,2,3}$ ( $\mathrm{g} / \mathrm{m}$ of row) and standard errors (in parentheses) of cool season forb species planted 19-20 Sept. and 13-15 Oct. 1986 in Foard County, Texas.

\begin{tabular}{|c|c|c|c|c|c|c|c|c|c|c|}
\hline \multirow[b]{2}{*}{ Species } & \multicolumn{9}{|c|}{ Monthly phyomass } & \multirow[b]{2}{*}{ Species mean } \\
\hline & Dec. 86 & April 87 & May 87 & June 87 & July 87 & Aug. 87 & Sept. 87 & Oct. 87 & Nov. 87 & \\
\hline & \multicolumn{10}{|c|}{ (g) row) } \\
\hline Alfalfa & - & $\begin{array}{l}19.2 \mathrm{abc} \\
(2.0)\end{array}$ & $\begin{array}{r}11.7 \mathrm{a} \\
(1.6)\end{array}$ & $\begin{array}{r}41.1 \mathrm{a} \\
(6.0)\end{array}$ & $\begin{array}{r}51.8 \mathrm{a} \\
(7.1)\end{array}$ & $\begin{array}{r}25.3 \mathrm{a} \\
(4.1)\end{array}$ & $\begin{array}{r}24.1 \mathrm{a} \\
(4.6)\end{array}$ & $\begin{array}{r}6.2 \mathrm{a} \\
(2.4)\end{array}$ & $\begin{array}{r}9.4 \mathrm{a} \\
(1.8)\end{array}$ & $\begin{array}{l}23.6 \\
(5.6)\end{array}$ \\
\hline Engelmann daisy & - & $\begin{array}{c}0.0 \mathrm{a} \\
(0.0)\end{array}$ & $\begin{array}{r}4.0 \mathrm{a} \\
(1.2)\end{array}$ & $\begin{array}{r}8.5 b \\
(3.0)\end{array}$ & $\begin{array}{l}9.4 \mathrm{~b} \\
(2.4)\end{array}$ & $\begin{array}{l}4.0 \mathrm{a} \\
(1.6)\end{array}$ & $\begin{array}{r}5.2 \mathrm{a} \\
(2.3)\end{array}$ & $\begin{array}{r}0.5 \mathrm{a} \\
(0.4)\end{array}$ & $\begin{array}{l}2.0 \mathrm{a} \\
(0.8)\end{array}$ & $\begin{array}{l}4.2 \\
(1.2)\end{array}$ \\
\hline Sainfoin & - & $\begin{array}{l}17.3 \mathrm{ab} \\
(1.8)\end{array}$ & $\begin{array}{r}21.8 \mathrm{a} \\
(3.9)\end{array}$ & $\begin{array}{r}34.8 \mathrm{a} \\
(3.8)\end{array}$ & $\begin{array}{l}45.5 \mathrm{a} \\
(11.6)\end{array}$ & $\begin{array}{l}27.0 \mathrm{a} \\
(5.2)\end{array}$ & $\begin{array}{l}14.0 \mathrm{a} \\
(2.8)\end{array}$ & $\begin{array}{l}10.0 \mathrm{a} \\
(3.2)\end{array}$ & $\begin{array}{l}10.3 \mathrm{a} \\
(2.3)\end{array}$ & $\begin{array}{l}22.6 \\
(4.4)\end{array}$ \\
\hline Howard subclover & $\begin{array}{r}22.4 \mathrm{a} \\
(5.9)\end{array}$ & $\begin{array}{l}59.4 d \\
(11.0)\end{array}$ & $\begin{array}{r}0.0 \mathrm{a} \\
(0.0)\end{array}$ & $\begin{array}{r}0.2 b \\
(0.1)\end{array}$ & $\begin{array}{r}0.7 \mathrm{~b} \\
(0.3)\end{array}$ & - & - & - & - & $\begin{array}{l}16.5 \\
(11.5)\end{array}$ \\
\hline Nungarin subclover & $\begin{array}{r}21.8 \mathrm{a} \\
(7.3)\end{array}$ & $\begin{array}{l}39.4 \mathrm{bc} \\
(5.9)\end{array}$ & $\begin{array}{r}0.0 \mathrm{a} \\
(0.0)\end{array}$ & $\begin{array}{l}0.0 \mathrm{~b} \\
(0.0)\end{array}$ & $\begin{array}{c}0.0 \mathrm{~b} \\
(0.0)\end{array}$ & - & - & - & - & $\begin{array}{c}12.2 \\
(8.0)\end{array}$ \\
\hline
\end{tabular}

'Means followed by different letters within months are different $(P<0.05)$. 
Table 3. Monthly mean phytomass ${ }^{1,2}(\mathrm{~g} / \mathrm{m}$ of planted row) and crude protein (\% CP)(standard errors in parentheses) of warm season forb species planted 16-17 May 1987 in Foard County, Texas.

\begin{tabular}{|c|c|c|c|c|c|c|c|c|c|c|c|c|}
\hline \multirow{3}{*}{$\begin{array}{l}\text { Species } \\
\text { Awnless } \\
\text { bush sunflower }\end{array}$} & \multicolumn{12}{|c|}{ Evaluation month } \\
\hline & \multicolumn{2}{|c|}{ July } & \multicolumn{2}{|c|}{ Aug. } & \multicolumn{2}{|c|}{ Sept. } & \multicolumn{2}{|c|}{ Oct. } & \multicolumn{2}{|c|}{ Nov. } & \multicolumn{2}{|c|}{ Species mean } \\
\hline & $\begin{array}{c}(\mathrm{g} / \mathrm{m}) \\
21.4 \\
(7.6)\end{array}$ & $\begin{array}{c}(\% \mathrm{CP}) \\
27.7 \\
(0.5)\end{array}$ & $\begin{array}{l}(\mathrm{g} / \mathrm{m}) \\
112.1 \\
(33.3)\end{array}$ & $\begin{array}{c}(\% \mathrm{CP}) \\
14.7 \\
(0.2)\end{array}$ & $\begin{array}{l}(\mathrm{g} / \mathrm{m}) \\
146.0 \\
(35.9)\end{array}$ & $\begin{array}{c}(\% \mathrm{CP}) \\
16.7 \\
(1.4)\end{array}$ & $\begin{array}{l}(\mathrm{g} / \mathrm{m}) \\
191.2 \\
(38.9)\end{array}$ & $\begin{array}{c}\% \mathrm{CP}) \\
13.4 \\
(0.7)\end{array}$ & $\begin{array}{l}(\mathrm{g} / \mathrm{m}) \\
105.0 \\
(30.9)\end{array}$ & $\begin{array}{c}(\% \mathrm{CP}) \\
8.0 \\
(0.6)\end{array}$ & $\begin{array}{l}(\mathrm{g} / \mathrm{m}) \\
115.1 \\
(28.0)\end{array}$ & $\begin{array}{c}(\% \mathrm{CP}) \\
16.1 \\
(3.2)\end{array}$ \\
\hline $\begin{array}{l}\text { Illinois } \\
\text { bundleflower }\end{array}$ & $\begin{array}{l}41.9 \\
(6.9)\end{array}$ & $\begin{array}{l}21.1 \\
(1.1)\end{array}$ & $\begin{array}{l}225.8 \\
(23.7)\end{array}$ & $\begin{array}{l}13.2 \\
(0.2)\end{array}$ & $\begin{array}{l}150.7 \\
(24.6)\end{array}$ & $\begin{array}{l}10.9 \\
(0.8)\end{array}$ & $\begin{array}{l}127.4 \\
(26.0)\end{array}$ & $\begin{array}{l}7.6 \\
(0.4)\end{array}$ & $\begin{array}{l}55.3 \\
(9.5)\end{array}$ & $\begin{array}{l}4.3 \\
(0.1)\end{array}$ & $\begin{array}{l}120.2 \\
(33.5)\end{array}$ & $\begin{array}{l}11.4 \\
(2.8)\end{array}$ \\
\hline
\end{tabular}

${ }^{1}$ No differences $(P>0.05)$ were found among species means or evaluation-month means, and species $\times$ evaluation-month interaction was not significant $(P>0.05)$.

${ }^{2} \mathrm{~N}=8$ samples per biomass mean, $\mathrm{N}=4$ samples per \%CP mean.

exception was Engelmann daisy, which produced some new growth of higher CP values in October and November 1987. Although no differences were detected among warm-season forb species' $C P$ means ( $P>0.05$ ) (Table 3 ), their $C P$ values were numerically greater than those of the cool-season forb species from July to September 1987. The CP values of awnless brush sunflower and Illinois bundleflower declined as they matured in October and November 1987, as did the CP values of the cool-season forb species.

\section{Discussion}

\section{Browse Species}

Four-wing saltbush demonstrated potential for winter browse species establishment. Dryer than average environmental conditions during this study (Fig. 1) may have impacted establishment. Environmental conditions can not be controlled when conducting a rangeland study, hence they may have a strong impact on any final outcome.

Although percent establishment of four-wing saltbush was low, seedlings were able to produce a significant amount of aboveground phytomass as measured by volume. This shrub demonstrated potential as a winter forage browse species. Thus, fourwing may be considered as a supplemental winter forage species in the southern mixed prairie. Although we did not have enough four-wing plant material available to analyze for CP content, other studies in Texas have shown that percent $\mathrm{CP}$ and digestible organic matter in four-wing saltbush leaves exceed the minimum requirements of cattle, sheep, goats, and deer throughout the year (Peter- son et al. 1987). In addition, four-wing saltbush was found to be a good potential source of fall and winter nutrients in the Oklahoma tallgrass prairie (Stidham et al. 1982).

The warm-season browse species tested, littleleaf lead-tree, established successfully despite dry conditions. In addition to the high percent establishment of littleleaf lead-tree, its leaves were determined to be high in CP, a good indication of their nutritive quality. Whisenant et al. (1985) found that littleleaf lead-tree CP ranged from $15 \%$ to $34 \%(\bar{x}=22 \%)$ from May to November with highest values in the spring and autumn. The variation in leaf CP found between plots in this study may have been due to seedling density. On plot 2 seedlings were half as dense, thus less crowded.

Littleleaf lead-tree seedlings were the only shrubs consumed by lagomorphs during this study. Several seedlings were eaten to ground level, yet resprouted rapidly. These seedlings appeared to be very hardy. No shrub seedlings were affected by grasshoppers.

The hot, dry summer season in central and south Texas is often critically deficient in available nutritious forage (Teer et al. 1965, Bryant et al. 1980, Whisenant et al. 1985). In addition, late-summer and fall herbaceous forage quality declines with maturity (Moen 1973:309). In this study, littleleaf lead-tree produced available leaf material high in CP from July to November. The amount of CP in littleleaf lead-tree leaves sampled in October 1987 was sufficient to support most physiological stages of deer (Verme and Ullrey 1984:117). Based on percent establishment, forage production, and nutritional quality, littleleaf lead-tree appeared to have excellent potential as a spring-through-fall forage for deer in the southern mixed prairie.

Table 4. Monthly mean crude protein ${ }^{1,2}(\%)$ and standard errors (in parentheses) of cool season forb species planted 19-20 Sept. and 13-15 0ct. 1986 in Foard County, Texas.

\begin{tabular}{|c|c|c|c|c|c|c|c|c|c|c|}
\hline \multirow[b]{2}{*}{ Species } & \multicolumn{9}{|c|}{ Monthly crude protein } & \multirow[b]{2}{*}{ Species mean } \\
\hline & Dec. 86 & April 87 & May 87 & June 87 & July 87 & Aug. 87 & Sept. 87 & Oct. 87 & Nov. 87 & \\
\hline Alfalfa & -3 & $26.2 \mathrm{a}$ & $\begin{array}{l}18.2 \mathrm{a} \\
(0.2)\end{array}$ & $\begin{array}{l}22.0 \mathrm{a} \\
(0.1)\end{array}$ & $\begin{array}{c}17.4 \mathrm{~b} \\
(0.6)\end{array}$ & $\begin{array}{c}-(\%)-- \\
12.5 \mathrm{a} \\
(0.5)\end{array}$ & $\begin{array}{l}12.6 \mathrm{a} \\
(0.5)\end{array}$ & $\begin{array}{c}13.1 \mathrm{~b}^{6} \\
(0.8)\end{array}$ & $\begin{array}{c}9.8 \mathrm{a} \\
(0.3)\end{array}$ & $\begin{array}{l}16.5 \\
(2.0)\end{array}$ \\
\hline Engelmann daisy & - & - & $\begin{array}{c}16.1 \mathrm{ab} \\
(0.5)\end{array}$ & $\begin{array}{c}18.5 \mathrm{bc} \\
(1.1)\end{array}$ & $\begin{array}{r}14.6 \mathrm{c} \\
(0.6)\end{array}$ & $\begin{array}{l}9.3 a \\
(0.8)\end{array}$ & $\begin{array}{r}9.8 \mathrm{a} \\
(0.3)\end{array}$ & $\begin{array}{l}18.1 \mathrm{a}^{5} \\
(0.4)\end{array}$ & $\begin{array}{c}13.5 \mathrm{a}^{4} \\
(2.6)\end{array}$ & $\begin{array}{c}14.3 \\
(1.4)\end{array}$ \\
\hline Howard subclover & $\begin{array}{c}20.1 \mathrm{a}^{4} \\
(2.9)\end{array}$ & $\begin{array}{c}20.5 \mathrm{ac} \\
(0.8)\end{array}$ & - & $\begin{array}{l}20.7 \mathrm{ab}^{5} \\
(0.6)\end{array}$ & $\begin{array}{c}20.0 \mathrm{a}^{4} \\
(0.9)\end{array}$ & - & - & - & - & $\begin{array}{c}20.3 \\
(0.2)\end{array}$ \\
\hline Nungarin subclover & $\begin{array}{c}23.1 \mathrm{a}^{4} \\
(1.6)\end{array}$ & $\begin{array}{c}18.4 \mathrm{bc} \\
(0.6)\end{array}$ & - & - & - & - & - & - & - & $\begin{array}{l}20.8 \\
(2.4)\end{array}$ \\
\hline
\end{tabular}

${ }^{\mathrm{I}}$ Means followed by different letters within columns are different $(P<0.05)$

${ }^{2} \mathrm{~N}=8$ samples per mean unless otherwise indicated.

3Sample too small to analyze

$\mathrm{N}=4$ samples per mean.

$5 \mathrm{~N}=2$ samples per mean.

${ }^{6} \mathrm{~N}=6$ samples per mean. 


DEC APR MAY JUN JUL AUG SEP OCT NOV

Fig. 2. Peak crude protein and biomass production periods of successfully introduced browse and forb species in the southern mixed prairie of Texas.

Forb Species

Subterranean clover varieties had good phytomass production in the first cool season (December 1986-April 1987); however, there was much less precipitation in the second cool season (December 1987-April 1988) (Fig. 1) and the subterranean clovers failed to reseed, and thus produced no measurable phytomass. Subterranean clovers are adapted to climates with relatively warm, moist winter and dry summers (Smith et al. 1986, Holt and Haferkamp 1987). The southern mixed prairie is characterized by annual fluctuations in the amount of precipitation received. Thus, Howard and Nungarin subterranean clovers may not be dependable winter forage species in this region during dry years.

Alfalfa and sainfoin were productive through July 1987. Engelmann daisy consistently produced less forage than the other coolseason species. The decline in phytomass of alfalfa and sainfoin from July 1987 to November 1987 coincided with the lack of precipitation and low observed soil moisture. In addition, consumption by grasshoppers and lagomorphs contributed to the decline in phytomass of alfalfa and sainfoin.

Illinois bundleflower and awnless bush sunflower were highly productive under the conditions of this study. These species appear to have good potential as summer through autumn forage.

The variety of forbs planted in this study provided forage at different phenological stages, or maturity, through all seasons, thus providing digestible material for wildlife throughout the year. Forage species in an immature phenological stage are more digestible and contain more protein than those in mature stages (Moen 1973:309). Howard and Nungarin subterranean clovers provided forage from December to April when adequate precipitation was available. Alfalfa and sainfoin provided forage from May to July, and Illinois bundleflower and awnless bush sunflower provided forage from August to November. All species planted were perennials or self-seeding annuals and possibly could persist for several years if precipitation was adequate.

Forbs introduced on the study sites provided CP concentrations within a 13 to $20 \%$ range through all months of the study, well above the minimum level of 6 to $7 \%$ required for deer to survive (Dietz 1965). The introduced forbs provided CP concentrations adequate for deer reproduction, growth, and antler development (French et al. 1956, Dietz 1965, Verme and Ullrey 1984, Sowell et al. 1985, Johnson et al. 1987).

\section{Conclusions}

The introduction of a warm-season shrub and warm-season forbs, and to a lesser degree, cool-season forbs, was relatively successful even under drought conditions. Littleleaf lead-tree, Illi- nois bundleflower, and awnless bush sunflower demonstrated high percent establishment, phytomass, and nutritive qualities. Alfalfa, sainfoin, and the subterranean clovers also performed well, although the clovers did not successfully re-seed during this study, perhaps due to inadequate fall and winter precipitation. Maintaining forage species that peak in phytomass production and CP levels at different months throughout the year, as illustrated in Figure 2, would provide reasonable good quantity and high quality forage at all times and offer potential to enhance deer nutrition and thus, deer numbers, in the southern mixed prairie.

The findings of this study were collected over 2 growing seasons in the southern mixed prairie region of Texas. Although it would have been optimal to replicate the entire planting scheme the second year and to collect data for a longer period of time, this scenario was not logistically feasible. Future studies should pursue additional plantings to allow determination of response of these and other forage species to additional environmental factors. Our results do, however, allow some preliminary recommendations. To provide a desirable forage combination from summer to fall, we recommend a forage mixture of $30 \%$ awnless bush sunflower, $40 \%$ Illinois bundleflower, and $30 \%$ littleleaf lead-tree. A mixture of $20 \%$ subterranean clovers, $40 \%$ alfalfa, and $40 \%$ sainfoin should provide desirable forage and four-wing saltbush desirable browse during winter and spring. Cool-season agronomic grasses are eaten by deer in this region (Sowell et al. 1985) and may be considered as part of a planting strategy to supply winter nutrition (Wiggers et al. 1984). Because the browse and forb species we tested are perennials or self-seeding annuals, annual seasonal revegetation may not be required as it is for cereal grains. Introducing forage species to an area lacking certain seasonal nutritive components has the potential to improve the habitat for wildlife species. When there is an economic benefit derived from increasing the numbers of a particular species, the costs of introducing forage species may be defrayed. Several of the forage species evaluated in our study demonstrated good potential in the Texas southern mixed prairie.

\section{Literature Cited}

AOAC 1984. Official methods of analysis. Thirteenth ed. Assoc. Off. Anal. Chemists, Washington, D.C.

Bryant, F.C., and M.M. Kothmann. 1979. Variability in predicting edible browse from crown volume. J. Range Manage. 32:144-146.

Bryant, F.C., M.M. Kothmann, and L.B. Merrill. 1979. Diets of sheep, Angora goats, Spanish goats, and white-tailed deer under excellent range conditions. J. Range Manage. 32:412-417. 
Bryant, F.C., and M.M. Kothmann, and L.B. Merrill. 1980. Nutritive content of sheep, goat, and white-tailed deer diets on excellent condition rangeland in Texas. J. Range Manage. 33:410-414.

Bryant, F.C., and B. Morrison. 1985. Managing plains mule deer in Texas and Eastern New Mexico. Manage. Note 7. Range and Wildl. Manage., Coll. Agr. Sci. Texas Tech Univ., Lubbock.

Cook, C.W. 1972. Comparative nutritive values of forbs, grasses, and shrubs, p. 303-310. In: C.M. McKell (ed.), Wildland shrubs-their biology and utilization. U.S. Forest Serv. Gen. Tech. Rep. INT-1.

Cook, R.L., and W.F. Harwell. 1978. Big game investigations. Job 1. White-tailed deer population trends. Job Perf. Rep. Tex. Fed. Aid Proj. W-109-R-1.

Correll, D.S., and M.C. Johnston. 1979. Manual of the vascular plants of Texas. Univ. of Texas Print. Div., Austin.

Dietz, D.R. 1965. Deer nutrition research in range management. Trans. Amer. Wildl. and Natur. Resour. Conf. 30:274-285.

Dietz, D.R. 1972. Nutritive value of shrubs, p. 289-302. In: C.M. McKell (ed.), Wildland shrubs - their biology and utilization. U.S. Forest Serv. Gen. Tech. Rep. INT-1.

French, C.E., L.C. McEwen, N.D. Magruder, R.H. Ingram, and R.W. Swift. 1956. Nutrient requirements for growth and antler development in the white-tailed deer. J. Wildl. Manage. 20:221-232.

Herbel, C.H. 1986. Seeding shrubs in the field. Reclam. and Reveg. Res. 5:377-385.

Holt, E.C., and M.R. Haferkamp. 1987. Growth of introduced temperate legumes in the Edwards Plateau and South Texas Plains. J. Range Manage. 40:132-135.

Johnson, M.K., B.W. Delany, S.P. Lynch, J.A. Zeno, S.R. Schultz, T.W Keegan, and B.D. Nelson. 1987. Effects of cool-season agronomic forages on white-tailed deer. Wildl. Soc. Bull. 15:330-339.

Koos, W.M., and M.L. Dixon. 1964. Soil survey of Foard County, Texas. U.S. Soil Conserv. Serv. Tex. Agr. Exp. Sta. Serv. 1961, 14.

Leffel, R.C. 1973. Other legumes, p. 208-220. In: M.E. Heath, D.S. Metcalf, and R.F. Barnes (eds.), Forages: the science of grassland agriculture. Third ed. Iowa State Univ. Press, Ames.

Moen, A.N. 1973. Wildlife ecology: An analytical approach. W.H. Freeman and Co., San Francisco, Calif.
Petersen, J.L., D.N. Ueckert, R.L. Potter, and J.E. Huston. 1987. Ecotypic variation in selected four-wing saltbush populations in western Texas. J. Range Manage. 40:361-366.

Smith, G.R., R.D. Randel, and C. Bradshaw. 1986. Influence of harvest date, cultivar, and sample storage method on concentration of isoflavones in subterranean clover. Crop Sci. 26:1013-1016.

Smith, M. 1986. Wildlife in Texas: Probable and profitable. The Cattleman 72:88-102.

Sowell, B.F., B.H. Koerth, and F.C. Bryant. 1985. Seasonal nutrient estimates of mule deer diets in the Texas Panhandle. J. Range Manage. 38:163-167.

Steele, R.D.G., and J.H. Torrie. 1980. Principles and procedures of statistics. Second ed. McGraw-Hill Book Co., New York, N.Y.

Steinbach, D.W., and C.W. Ramsey. 1988. The Texas "Lease System": History and future, p. 54-68. In: D. Rollins (ed.), Recreation on rangelands: Promise, problems, projections. Symp. Proc. Soc. Range Manage., Corpus Christi, Tex.

Stidham, N.D., J. Powell, F. Gray, and P.L. Claypool. 1982. Establishment, growth, utilization, and chemical composition of introduced shrubs on Oklahoma tallgrass prairie. J. Range Manage. 35:301-304.

Teer, J.G., J.W. Thomas, and E.A. Walker. 1965. Ecology and management of white-tailed deer in the Llano Basin of Texas. Wildl. Monogr. 15 .

USDA Forest Serv. 1974. Seeds of woody plants in the United States. USDA Handb. 450.

Vanderhoof, R.E., and H.A. Jacobson. 1989. Effects of agronomic plantings on white-tailed deer antler characteristics. Paper presented at Twelfth Annu. Meeting Southeast Deer Study Group, Oklahoma City, Okla., Feb. 19-22.

Verme, L.J., and D.E. Ullrey. 1984. Physiology and nutrition, p. 91-118. In: L.K. Hall (ed.), White-tailed deer ecology and management. Stackpole Books, Harrisburg, Penn.

Vines, R.A. 1960. Trees, shrubs, and woody vines of the Southwest. Univ. Texas Press, Austin.

Whisenant, S.G., D.N. Ueckert, and J.E. Huston. 1985. Evaluation of selected shrubs for arid and semi-arid game ranges. J. Wildl. Manage. 49:524-527.

Wiggers, E.P., D.D. Wilcox, and F.C. Bryant. 1984. Cultivated cereal grains as supplemental forages for mule deer in the Texas Panhandle. Wildl. Soc. Bull. 12:240-245. 